\title{
XLIX Contribution to the Knowledge of the Amphipoda. On Three Niphargus Species (Fam. Gammaridae) from the Balkans
}

\author{
by
}

\author{
Gordan S. KARAMAN*
}

\section{INTRODUCTION}

The genus Niphargus is presented in the Balkans by a large number of species. There are more than 100 species and subspecies of this genus now known.

Recently was discovered the first member of the Niphargus carpathicus-group in Yugoslavia, N. deelemani G. Kar. 1973 from the cave Držina pecina near Pirot (eastern Serbia).

A second species of this group, $N$. adbiptus, n. sp., has been collected in the Ravanica cave in Serbia.

S. Karaman described in 1943 Niphargus stygius ravanicanus from the same cave (Ravanica). As he confused two species in his description of $N$. st. ravanicanus $(N$. st. ravanicanus $+N$. adbiptus), below is a short diagnosis of $N$. st. ravanicanus based on the holotype.

Niphargus valachicus (Dobr. Man. 1933) known from Central Europe, Yugoslavia, Hungary and Rumania, now is known from Bulgaria also (Devnja).

\section{Niphargus stygius ravanicanus S. Karaman 1943}

fig. I

Syn.: Niphargus stygius ravanicanus (part.) S. Karaman 1943, p. 151, figs. 14-20, 22, 25-27. Niphargus ravanicanus (part.) S. Karaman 1958, p. 14.

S. Karaman described this species from the cave Ravanica in Serbia, based on one adult female of $12 \mathrm{~mm}$ collected by dr. M. Radovanović and on 4 juvenile specimens collected by cir. S. Stanković.

After reexamination of this material, I concluded that only the female belongs to this species, and that 4 juvenile specimens belong to another species, N. adbiptus, n. sp. described now from the same cave.

A short diagnosis of $N$. stygius ravanicanus is as follows: Body-length of single female $12 \mathrm{~mm}$. Artenna 1 shorter than half of the body-length, its principal flagellum 20-articulate, articles with one short aesthetasc each.

Antenna 2 shorter, medially setose, its flagellum 10-articulate (see fig. 14 of S. Kar. 1943).

\footnotetext{
* Institute of Biology, Titograd, Yugoslavia
} 
Maxilla 1: inner lobe with 2-3 distal short setae, outer lobe with 7 spines provided with one lateral tooth each (only inner spine bears 4 lateral teeth), palp with 6 distal setae (see fig. 18 of S. Kar. 1943). Maxilliped: inner lobe with 2 distal spines. Mandible: third palpar article provided with 20 D-setae and 4 long E-setae at margin, 3 groups of 1-2 B-setae on inner surface and one A-group of setae on outer surface (fig. I, 1).

Coxae 1-4 nearly quadrate (figs. I, 2-5). Gnathopod 1: article 6 very slightly longer than broad, with 5 groups of setae at posterior margin, palm somewhat inclinated, dactyl with several setae at superior margin (see fig. 19 of S. Kar. 1943).

Gnathopod 2: article 6 slightly broader than long, with 7 groups of setae at posterior margin, palm slightly inclinated, dactyl with several setae at superior margin (see fig. 20 of S. Kar. 1943).

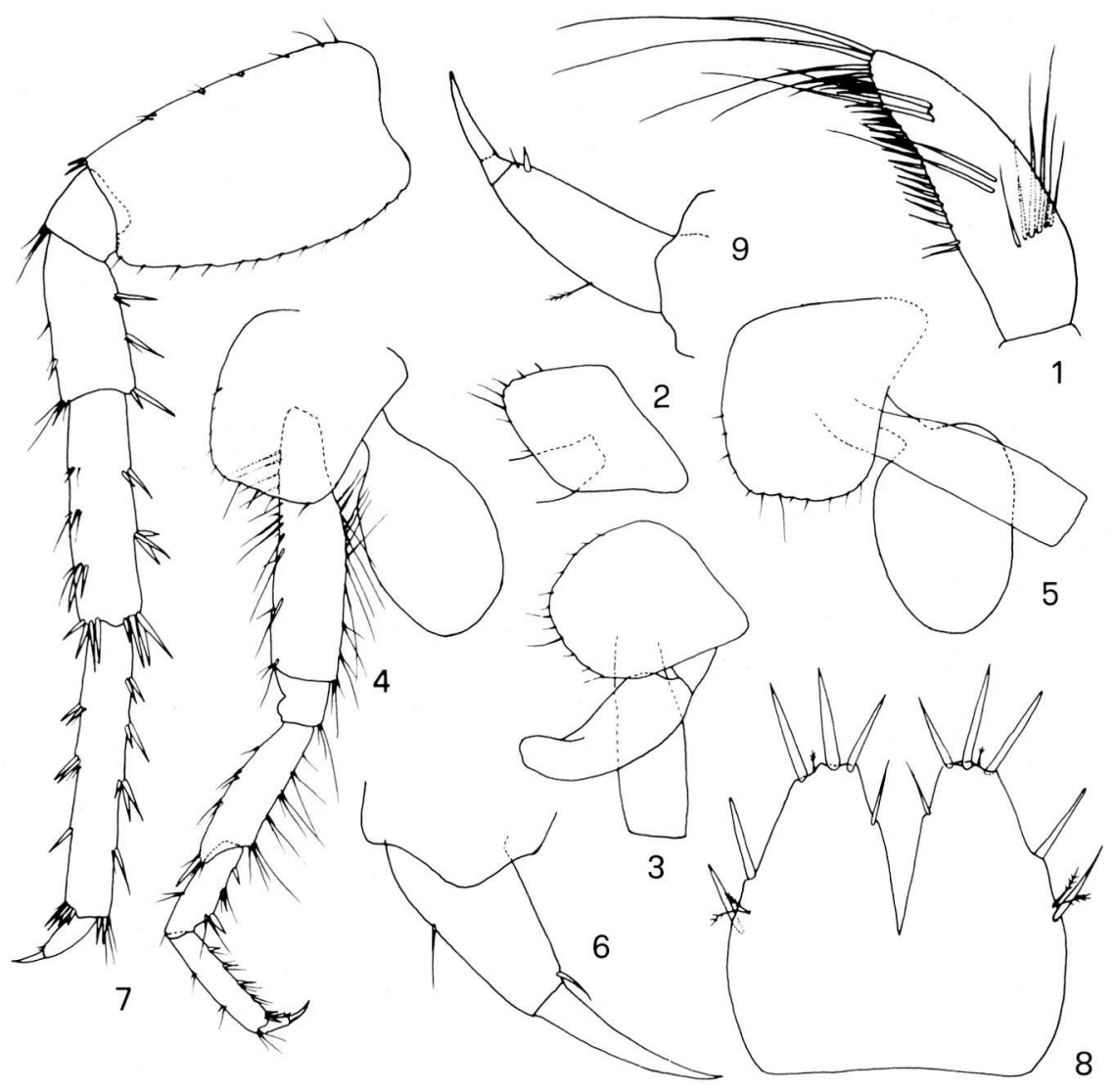

Fig. I. Niphargus stygius ravanicanus, S. Kar., Ravanica cave, femaie $12 \mathrm{~mm}$, (holotype): 1= palp of maxilliped, inner face; $2=\operatorname{coxa} 1 ; 3=\operatorname{coxa} 2 ; 4=\operatorname{pereopod} 3 ; 5=\operatorname{coxa} 4 ; 6=$ dactyl of pereopod $3 ; 7=$ pereopod $7 ; 8=$ telson; $9=$ dactyl of pereopod 7 . 
Pereopods 3-4 similar, articles with longer setae at posterior margin, dactyl medially strong, with the nail slightly shorter than the remaining part of dactyl itself (figs. I, 4,6).

Pereopods 5-7 relatively short, also stygius-like, dactyls medially strong, with one spine at inner margin, nail nearly 65 percent as long as the remaining part of dactyl itself. Article 2 more or less ovoid, its distoposterior lobe marked (figs. I, $7,9)$.

Pleopods with 2 retinacula each. Epimere 1-3 with obtuse distoposterior corner (see fig. 27 of S. Kar. 1943).

Uropods 1-2: peduncle lacking distal protrusion, inner ramus somewhat longer than outer one, both with marginal and distal spines.

Uropod 3: inner ramus scale-like, outer ramus 2-articulate, second article nearly 50 percent as long as the first one (see fig. 26 of S. Kar. 1943).

Telson broader than long, stygius-like, nearly 60 percent incised, with 3 distal and several marginal spine on each lobe, no spines on dorsal surface (fig I, 8). The pair of a short plumose setae appears in the middle of the telson length.

Gills on thoracal segment 2 slender (fig. I, 3), on thoracal segment 3-4 ovoid (figs. I, 4,5).

Material examined. The preparate of a single ovig. female of $12 \mathrm{~mm}$ from Ravanica cave, 193"' (leg. M. Radovanović).

Holotype: female, $12 \mathrm{~mm}$ from Ravanica-cave. It is deposited in my collection in Titograd.

Remarks and Affinity. The single female of ssp. ravanicanus belong to stygius group, based on the shape of telson, of pereopods 3-7, of gnathopods 1-2, uropods $1-3$, epimere etc.

$N$. st. ravanicanus differs from $N$. stygius stygius by the shape of gnathopods, telson etc.

Since this group of Niphargus stygius must be revised, I retain the ssp. ravanicanus as before, with one subspecies of $N$. stygius (Schiödte), but the precise position of this subspecies must be studied together with all other species of this group.

All figures are described from the preparate of holotype, which may have a slight deformation of single appendages in this specimen.

Niphargus adbiptus n. sp.

figs. II-IV

Syn.: Niphargus stygius ravanicanus (part.) S. Karaman 1943, p. 151, figs. 17, 21 , 24.

Niphargus ravanicanus (part.) S. Karaman 1958, p. 14, fig. 12.

Description of the male. Body-length $9 \mathrm{~mm}$. Lateral cephalic lobes rounded, body smooth, urosomite 1 with one dorsolateral seta, urosomite 2 with one dorsolateral spine on each side.

Antenna 1 long, the proportion body: antenna 1 is 9:7; principal flagellum 


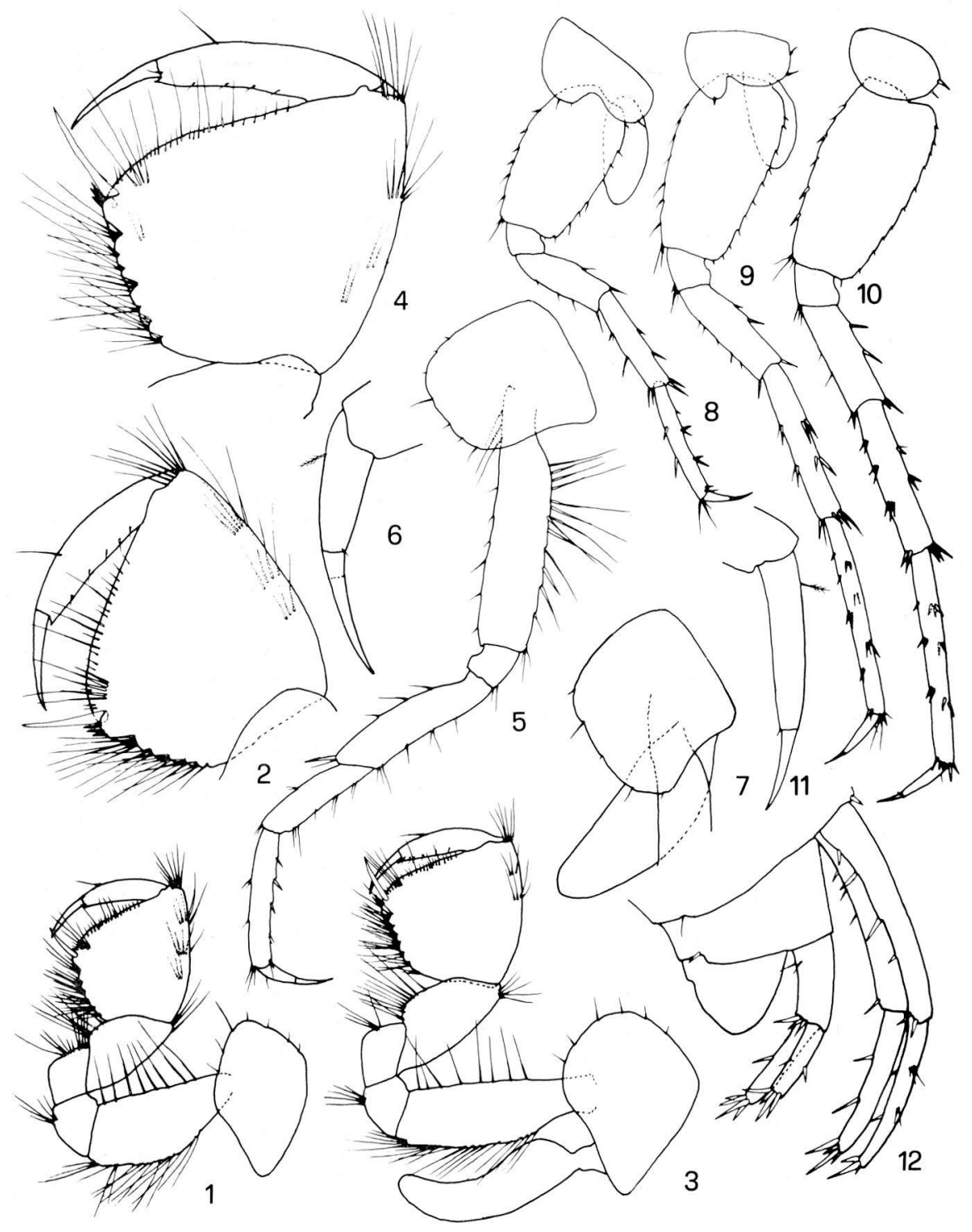

Fig. II. Niphargus adbiptus, n. sp., Ravanica cave, male $9 \mathrm{~mm}: 1,2=\operatorname{gnathopod} 1 ; 3,4=$ gnathopod $2 ; 5,6=$ pereopod $3 ; 7=\operatorname{coxa} 4 ; 8=$ pereopod $5 ; 9=$ pereopod $6 ; 10,11=$ pereopod $7 ; 12=$ urosome with uropods. 
25-articulate, each article with one short aesthetasc, accessory flagellum 2-articulate, antennal gland cone short.

Antenna 2 much shorter than antenna 1, its flagellum 8-articulate. Maxille 1: inner lobe with one distal seta, outer lobe with 7 spines bearing usually only lateral tooth each (only 1-2 median spines bear 2 lateral teeth and inner spine bears 4-6 lateral teeth); palp biarticulate, with 8 distal setae (fig. III, 1). Inner lobe of maxilliped with 4 distal spines. Mandible: third palpar article with 18 marginal D-setae and 5 long E-setae, on outer surface appears one tuft of A-setae, on inner surface 3 tufts of 1-2 B-setae (fig. IV, 5).

Coxa 1 broader than long, coxae 2-4 nearly as long as broad, all provided with distal setae (figs. II, 1, 3, 5, 7). Coxae 5-7 progressively shorter (figs. II, 8-10).

Gnathopod 1: article 6 slightly longer than broad, with 6 tufts of setae at posterior margin, palm inclined to the middle of the length of article 6 , with one corner spine. Dactyl with slender nail provided with one median seta at superior margin (figs. II, 1, 2).

Gnathopod 2: it is broader than gnathopod 1, article 6 as long as broad, with less inclinated palm. Posterior margin of article 6 with 7 tufts of setae, dactyl with one median seta at superior margin (figs. II, 3, 4).

Pereopods 3-4 similar, with relatively slender articles, articles 4 and 6 are subequal in length, dactyl slender, with long nail nearly as long as the remaining part of dactyl itself. The articulation of the nail is visible (figs. II, 5, 6).

Pereopod 5: article 2 dilated posteriorly, but lacking distoposterior lobe, articles 3-6 slender, provided with spines at both margins (fig. II, 8).

Pereopods 6-7 similar in shape and spinulation, only article 2 is slightly longer; posterior part of article 2 dilated, its distoposterior lobe not produced. Dactyl very slender, 40 percent of the article 6 length, nail much shorter than the remaining part of dactyl (figs. II, 9, 10). The dactyls of pereopods 3-7 are progressively longer towards posterior, but their nail is progressively shorter towards posterior pereopod (figs. II, 6, 11).

Pleopods with numerous retinacula: pleopod 1 with $6-7$ retinacula, pleopods $2-3$ with 8 retinacula each.

Epimere 1-3 with subrounded distoposterior portion (corner), epimere 2-3 with several subdistal spines (fig. III, 2).

Uropod 1: peduncle longer than rami, lacking distal protrusion, rami slightly flattened dorsoventrally. Outer ramus very slightly longer than inner one, both rami with several lateral and distal spines (fig. II, 12). Uropod 2: inner ramus longer than outer one, both with lateral and distal spines (fig. II, 12).

Uropod 3: long and slender (fig. III, 3), inner ramus scale-like, provided with 2 distal spines; outer ramus biarticulate, second article nearly as long as the first one.

Telson longer than broad, with numerous long spines at distal and lateral margin. One spine appears on distal surface of each lobe (fig. III, 4). The pair of the plumose setae appears in the middle of telson length.

Gills on thoracal segment 2 long and halfmoon-like, gills on thoracal segments 3-6 more or less ovoid (figs. II, 3, 7-9).

The female. She is similar to the male (the length of antenna 1 , shape of 


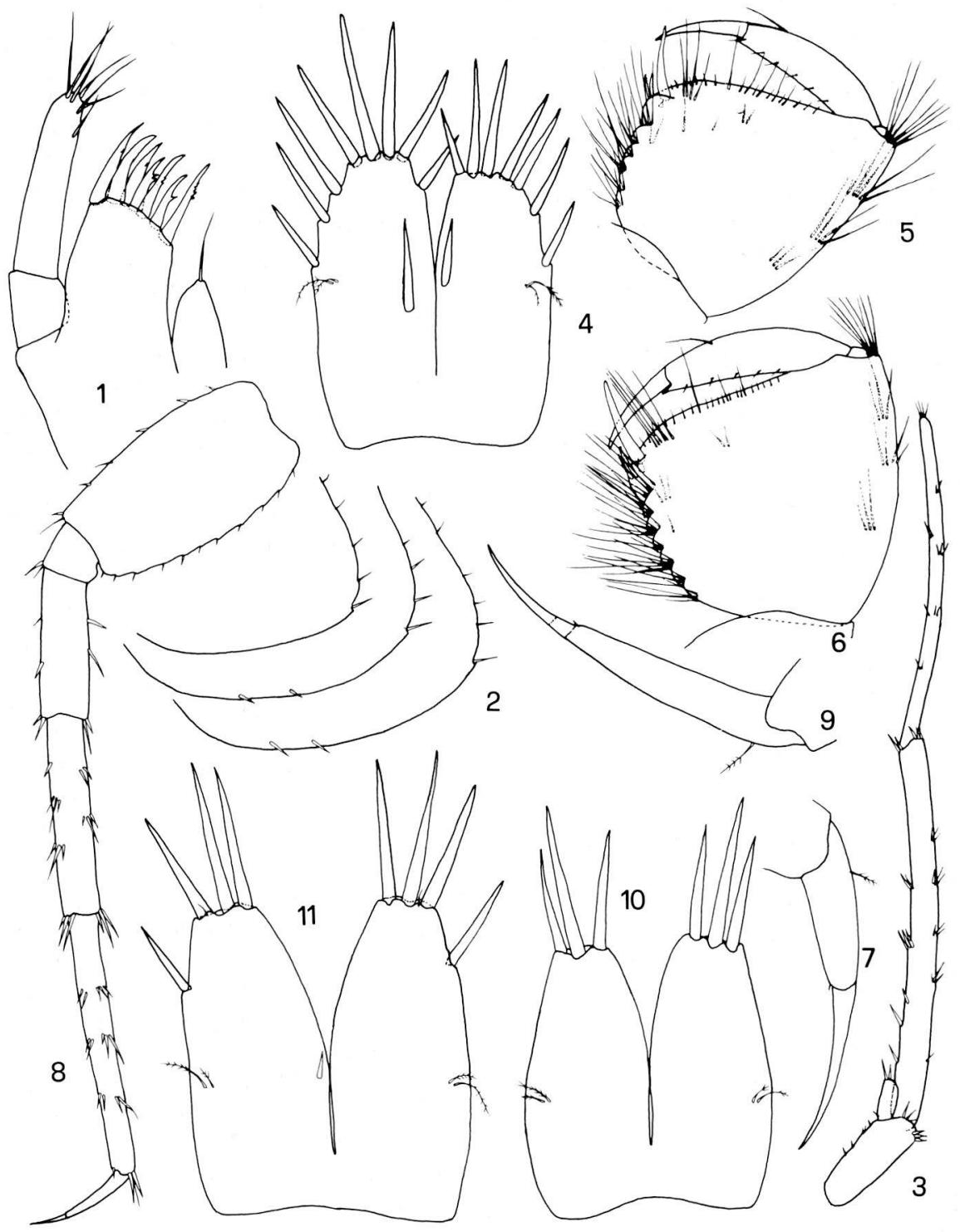

Fig. III. Niphargus adbiptus, n. sp., Ravanica cave, male $9 \mathrm{~mm}: 1=$ maxilla $1 ; 2=$ epimere; $3=$ uropod $3 ; 4=$ telson.

female, $9 \mathrm{~mm}: 5=$ gnathopod $1 ; 6=$ gnathopod $2 ; 7=$ dactyl of pereopod $3 ; 8,9=$ pereopod $7 ; 10=$ telson of ovig. female, $7 \mathrm{~mm} ; 11=$ telson, female $11 \mathrm{~mm}$. 
epimere, urosomites, dactyls of pereopods, uropods 1-2). Article 6 of gnathopods 1-2 like to that of the males (adult specimens of $7 \mathrm{~mm}$ ), or slightly broader (adult specimens of $9 \mathrm{~mm}$ ) (figs. III, 5, 6), coxae 1-4 like those of the males (figs. IV, 1-4). Pleopod 1 with 6 retinacula, pleopods 2-3 with 7 retinacula each. Pereopod 7 slightly broader than that of the male (figs. III, 8, 9).

Uropod 3: long and slender, second article of outer ramus nearly 40 percent of the length of the first one (fig. IV, 14). Teison longer than broad, with 3 distal spines and one lateral spine on each lobe. Telson of ovig. female of $7 \mathrm{~mm}$ has absence of lateral spine. The pair of a short plumose setae appears less than half of telson length (figs. III, 10, 11). Oostegyts broad. Gills like those of the males.

Variability. The spinulation of telson, the position of the pair of plumose setae on telson (males: females?), as well as the shape of article 6 of gnathopods 1-2 by the females in connection to the body-size (probably with the maturity of the specimens) are variable.

The shape of epimere, length of antenna 1, high number of retinacula, the shape of dactyl of gnatho pods 1-2 and pereopods are constant.

Material examined. Ravanica cave, 195?, single adult male (leg. T. Petkovski et C. Bogoevski); Ravanica, 195? , several females (leg. T. Petkovski et C. Bogoevski); Ravanica-cave, 1933, 4 juvenile specimens (leg. S. Stanković) (preparates).

Type locality: Ravanica-cave, Serbia.

Holotype: male of $9 \mathrm{~mm}$ from Ravanica cave; it is deposited in my collection in Titograd.

Remarks and Affinity. It seems that the specimens of the first and second sample (male and females) belong to the same new species, $N$. adbiptus. Slightly doubtful is the shape of telson, especially the position of the pair of plumose setae on outer margin of telson lobes. As the differences are very small, I think the females of the second sample belong to the same new species with the single male from Ravanica, $N$. cidbiptus.

$N$. adbiptus belong to the group of carpathicus-inopinatus (higher number of retinacula, the shape of pereopods, telson etc.). $N$. adbiptus differs from $N$. carpathicus Dobr. Man. 1939, N. romanicus Dobr. Man. Pusc. 1953, N. affinis Dobr. Man. Pusc. 1953, N. variabilis Dobr. Man. Pusc. 1953, N. molnaris Mehely 1927 and $N$. inopinatus Schell. 1932 in addition to everything else by the rounded epimere 1-3.

From Serbia is known one other member of carpathicus group, N. deelemani G. Kar. 1973, described from Drzina pecina-cave near Pirot. N. adbiptus differs from $N$. deelemani by rounded epimere 1-3 (by deelemani obtuse), by more inclinated palm of article 6 on gnathopod 1, by more slender gills on second thoracal segment, by more slender dactyl of pereopods $3-7$, by less number of setae on inner lobe of the first maxilla, by the shape of uropods 1-3 and telson, by higher number of retinacula (by deeleman only $3-4$ ), longer antenna 1 etc. 
Niphargus valachicus (Dobr. Manolache 1933)

fig. IV

Syn.: Niphargus tatrensis valachicus Dobreanu, Manolache 1933, p. 104, figs. 2-4. Niphargus valachicus S. Karaman 1934, p. 332; S. Karaman 1950, p. 11, figs. 1-12; Car. Dobr. Manolache 1955, p. 312, figs. 290-293.

Material examined. Devnja, 12 July, 1942 (Bulgaria), single male of $9.3 \mathrm{~mm}$, accompanied by Gammarus sp.

Distribution. Yugoslavia (S. Karaman 1934, 1950), Rumania (Dobr., Manolache 1933; Dobr. Man., Carausu 1955), Hungary (Dudich 1941), Czechoslovakia (Straškraba 1972), Bulgaria (present paper).

Remarks and Affinity. Our male was a non adult specimen, but it manifests all the characteristics of $N$. val. valachicus (the shape of epimere, of pereopods, the protrusion on distal margin of uropod 1 peduncle, telson etc.).

The article 6 of gnathopods 1-2 is slightly narrower and dactyl of pereopods 3-7 provided with a smaller number of spines at inner margin than those of the adult specimens of $N$. valachicus, but this is due to the small body-size of our specimen.

\section{ACKNOWLEDGMENTS}

I am indebted to prof. T. Petkovski and Č. Bogoevski from the Museum of Natural History in Skopje and prof. I. Buresch and V. Georgievski from the Museum of Natural History in Sofia for collected material of Amphipoda.

\section{SUMMARY}

Three Niphargus species from the Balkans are studied. Niphargus adbiptus, n. sp. is described from Ravanica cave in Serbia. Niphargus stygius ravanicanus S. Kar. 1943 from the same cave (Ravanica) is redescribed. N. valachicus Dobr. Man. 1933, is newly recorded from Bulgaria (Devnja).

\section{RÉSUMÉ}

Etude de trois espèces de Niphargus de la région des Balkans. $N$. adbiptus n. sp. est complètement décrit et figuré de la grotte du Ravanica (Serbie), il a de grandes affinités avec $N$. carpathicus Dobr. Man. 1939, mais il en diffère par certains caractères importants. N. stygius ravanicanus S. Kar. 1943 de la même grotte (Ravanica) est redécrit. Niphargus valachicus Dobr. Man. 1933 est signalé pour la première fois de Bulgarie (Devnja). 


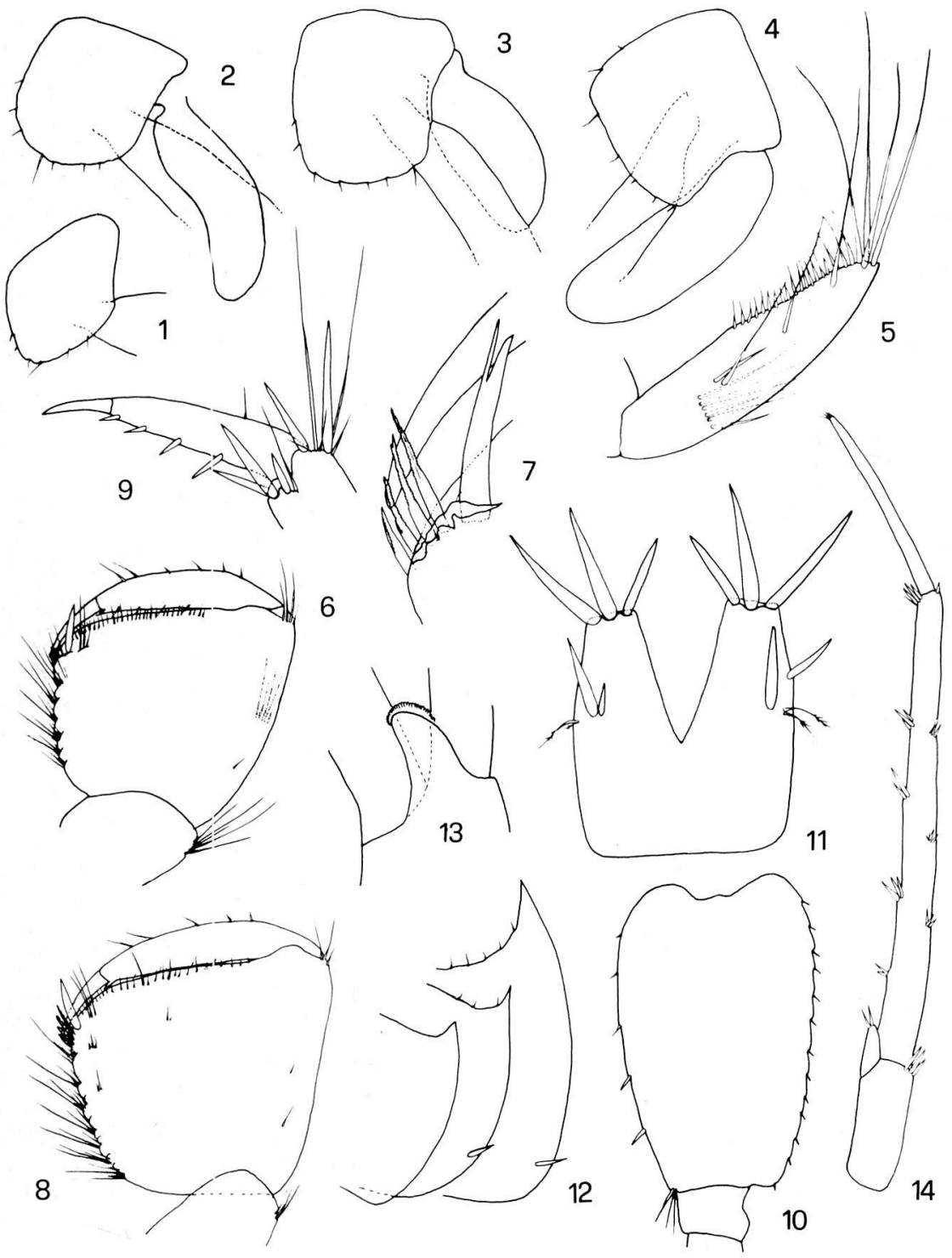

Fig. IV. Niphargus adbiptus, n. sp., Ravanica cave, female $9 \mathrm{~mm}: 1-4=$ coxae $1-4 ; 5=$ third palpar article of maxilliped, inner face; $14=$ uropod 3;

Niphargus valachicus Dobr. Man., Devnja, male $9.3 \mathrm{~mm}: 6,7=$ gnathopod 1;8= gnathopod $2 ; 9=$ dactyl of pereopod $6 ; 10=$ article 2 of pereopod $7 ; 11=$ telson; $12=$ epimere; $13=$ distal protrusion of uropod 1 peduncle. 


\section{REFERENCES}

CARAUSU, S., DOBREANU, E. and MANOLACHE, C., 1955. Amphipoda, forme salmastre si de apa dulce. Fauna Rep. Pop. Romine, Crustacea, 4 (4): 1-407.

DOBREANU, E. and MANOLACHE, C., 1933. Beitrag zur Kenntnis der Amphipoden Rumäniens. Notat. Biologicae, Bukarest, 3: 103-108.

DOBREANU, E. and MANOLACHE, C., 1939. III. Noui contributioni la studiul Amphipozilor din Romania. Niphargus carpathicus n. sp. Bul. Soc. Natur. Romania, 13 : 1-8.

DUDICH, H., 1941. Niphargus mediodanubialis sp. nov., die am weitestem verbreitete Niphargus Art des mittleren Donaubeckens. Fragmenta Faunistica, 4: 61-67.

KARAMAN, G., 1973. XLVIII. Contribution to the Knowledge of the Amphipoda. Two species of Family Gammaridae from Yugoslavia, Niphargus deelemani, n. sp. and Typhlogammarus algor, n. sp. Zoolog. Anzeiger (in press).

KARAMAN, S., 1934. VI. Beitrag zur Kenntnis jugoslavischer Süsswasseramphipoden. Zoolog. Anzeiger, 107 (11-12): 325-333.

KARAMAN, S., 1943. Über Serbische Niphargiden. Ohrid. Zbornik, Pos. Izd. Kralj. Akad. Beograd, 34 (3): 141-161.

KARAMAN, S., 1950. Über einen Niphargus aus unseren Sümpfen. Srp. Akad. Nauka, Pos. Izdanja, Knj. 163, (2): 26-32.

KARAMAN, S., 1958. Weitere Beiträge zur Kenntnis der Amphipoden und Isopoden Jugoslawiens und Griechenlands. Biološki Glasnik Zagreb, 11: 11-22.

SCHELLENBERG, A., 1935. Schlüssel der Amphipodengattung Niphargus mit Fundortangaben und mehreren neuen Formen. Zool. Anzeiger, 3 (7-8): 204-211.

STRASKRABA, M., 1972. L'état actuel de nos connaissances sur le genre Niphargus en Tchecoslovaquie et dans les pays voisins. Act. I. Coll. int. Niphargus Verona, Mem. Mus. Civ. St. Nat. Verona, 5: 35-46. 